\title{
THE JURIDICAL STATUS OF PRIVILEGED COMBATANTS UNDER THE GENEVA PROTOCOL OF 1977 CONCERNING INTERNATIONAL CONFLICTS*
}

\author{
W. Thomas Mallison† $\S$ \\ AND \\ Sally V. Mallison $\ddagger \S$
}

Contents

I. The Development of the Traditional Law $\ldots \ldots \ldots \ldots \ldots \ldots \ldots$. 5

1I. Analysis of Protocol I Criteria Concerning Privileged Com-

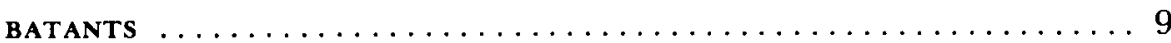
A. Preliminary Consideration of the New Criteria for Privileged Status ........................ 9
B. Article 1-Principles and Scope of Application ......... 10
C. Article 43 -Armed Forces .................... 19
D. Article 44 - Combatants and Prisoners of War .......... 20

III. Summary of Protocol I Categories of Persons Who Do Not

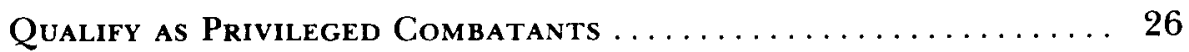

A. Unprivileged Combatants-Spies ............... 26

B. Unlawful Combatants-Mercenaries ............... 28

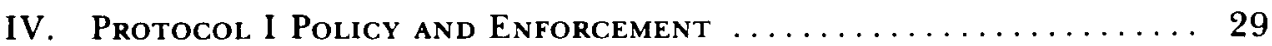

Appendices: Protocol I Articles Concerning Privileged Combatant STATUS

Appendix A. Preamble and Article $1 \ldots \ldots \ldots \ldots \ldots \ldots \ldots \ldots \ldots$

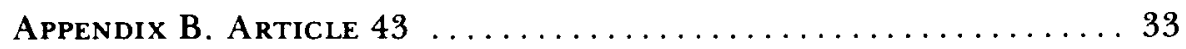

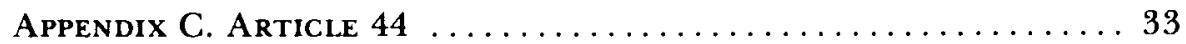

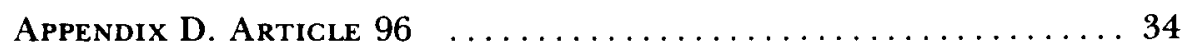

\footnotetext{
* Copyright 1979 by W. Thomas Mallison and Sally V. Mallison. This is a portion of a more comprehensive study concerning the international law of armed conflict.

$\dagger$ Professor of Law and Director, International and Comparative Law Program, George Washington University.

$\ddagger$ Research Associate, International and Comparative Law Program, George Washington University.

$\$$ The authors attended the Fourth Session of the Diplomatic Conference on the Reaffirmation and Development of the International Humanitarian Law Applicable in Armed Conflicts in Geneva as observers.
} 
The Development of the Traditional law

The term "privileged combatant" has been used to describe a combatant who meets the traditional Brussels-Hague-Geneva requirements for this status. ${ }^{1}$ These requirements are: (1) operating under military command; (2) wearing a fixed distinctive sign (or uniform for regulars); (3) carrying arms openly; and most important, (4) conducting military operations consistently with the laws and customs of war. A privileged combatant has a wellestablished position involving two basic legal rights in the international law of armed conflict. He has the legal right, limited by the laws and customs of war, to exercise coercion and violence in a public armed conflict situation. If captured by the enemy, he also has the legal right to prisoner of war (POW) status with its accompanying substantive and procedural benefits. Both regular armed forces and irregulars who are either fighting on behalf of or in association with a state-party to a conflict ${ }^{2}$ or fighting on behalf of their own public authority-party to a conflict ${ }^{3}$ come within the ambit of "privileged combatants."

In contrast, the term "unprivileged combatant" has usually referred to one who is neither a regular nor an irregular who complies with the traditional requirements. An "unprivileged combatant" fights for public purposes in a public armed conflict but fails to meet one or more of the requirements for privileged status. ${ }^{4}$ Spies and saboteurs are unprivileged as a rule, along with those irregulars who do not qualify for the privileged category. Unprivileged combatants who fall into the power of the enemy are entitled to the procedural and substantive protections of the Geneva Civilians Convention of $1949^{5}$ rather than the protections of the 1949 Prisoner of War Convention. The activities of unprivileged combatants (with the exception of war crimes, which

1. Brussels Declaration, August 27, 1874, art. 9, in Record of the Brussels Conference of 1874 , Parl. Papers Misc. No. 1, 76 Session Papers 43 (1875) (Gt. Brt.); 65 Brit. \& Foreign State Papers 1873-1874, at 1005-1014. $1067-1109$ (1881), 4 Martens Nouveau Recueil 219-26 (2d Ser.) [hereinafter cited as Brussels Declaration]. Hague Convention No. IV respecting the Laws and Customs of War on Land, October 18, 1907. Regulations Annexed, art. I, [1910] 36 Stat. 2277, T.S. No. 539, 2 Malloy, Treaties 2269 [hereinafter cited as Hague Convention IV of 1907]. Geneva Convention relative to the Treatment of Prisoners of War of August 12, 1949, art. 4A(2), [1955] 6 U.S.T. 3316 , at 3320, T.I.A.S. No. 3364, 75 U.N.T.S. 135 [hereinafter cited as the POW Convention]. The sources cited also appear in The LAw of Armed Conflicts: A Collection of Conventions, Resolutions, and Other Documents (D. Schindler \& J. Toman eds. 1973).

2. Mallison \& Mallison, The Juridical Status of Irregular Combatants Under the International Humanitarian Law of Armed Conflict, 9 CASE W. RES. J. INT'L L. 39, 50-53 (1977).

3. Id. at $53-55$.

4. Baxter, So-Called "Unprivileged Belligerency": Spies, Guerrillas, and Saboteurs, 28 BRIT. Y.B. INT'L L. 323, 327 (1951).

5. Geneva Convention relative to the Protection of Civilian Persons in Time of War of August 12, 1949, [1955] 6 U.S.T. 3516, T.I.A.S. No. 3365, 75 U.N.T.S. 287 [hereinafter cited as the Civilians Convention]. 
are equally criminal when committed by privileged combatants) are not violative of the law of armed conflict. ${ }^{6}$ At the same time, this law affords them very little protection against drastic sanctions, including the death penalty. For these reasons, it is accurate to characterize both unprivileged and privileged combatants as having lawful status in spite of the drastically different treatment to which each group may be lawfully subjected upon capture.

At the opposite extreme from both categories of lawful combatants are marauders on land and pirates at sea, who are the typical examples of individuals acting for the purpose of private gain. By definition they fail to meet the central public-purpose criterion for lawful combatant status.

As a result of the experiences of the Second World War, the Geneva POW Convention of 1949 amplified the doctrines applicable to privileged combatants somewhat by adding to the "militia and volunteer corps" specified in the Brussels Declaration of 1874 and in the Hague Conventions of 1899 and 1907 the new category of "organized resistance movements." 7 This Convention also provided that such movements were entitled to conduct their military operations "in or outside their own territory, even if this territory is occupied." This provision removes prior ambiguity about the lawfulness of these movements operating in occupied territory and their members being entitled to privileged combatant status, provided that they meet the four traditional criteria.

Because of the characteristics of the armed conflicts that have taken place since the termination of the Second World War, there has been an increasing view, manifested particularly by third world states and by organized resistance movements, that the four traditional criteria impose impractical and unworkable obligations upon irregulars operating in conflicts where guerrilla tactics are employed, including those within enemy-occupied territory.

These widespread views of the inadequacies of the traditional law were reflected at the Twentieth International Conference of the Red Cross in Vienna in 1965, which resolved that the International Committee of the Red Cross (ICRC) undertake the further development of the international humanitarian law. ${ }^{9}$ During the International Year for Human Rights in 1968, the International Conference on Human Rights met in Tehran. It adopted a resolution asking the General Assembly to invite the Secretary-General to study the steps that should be taken to secure better application of the existing humanitarian law and to consider " $[t]$ he need for additional humanitarian international conventions or for possible revision of existing [c]onventions." 10 The General As-

6. Baxter, supra note 4, at 342-44; Mallison \& Jabri, The Juridical Characteristics of Belligerent Occupation and the Resort to Resistance by the Civilian Population: Doctrinal Development and Continuity, 42 Geo. Wash. L. Rev. 185, 203-05 (1974).

7. POW Convention, supra note 1 , at art. $4 \mathrm{~A}(2), 6$ U.S.T. 3316 , at 3320.

8. Id.

9. Resolution XXVIII, 75 Int'L Rev. OF the Red Cross 305, 306 (1967).

10. Resolution XXIII, 90 Int'L Rev. OF THE Red Cross 473, 474 (1968). 
sembly responded by inviting the Secretary-General to undertake the study in consultation with the ICRC. ${ }^{11}$ The Secretary-General submitted three reports in 1969, 1970, and 1971, which, inter alia, suggested particular inadequacies in the existing law of armed conflict. ${ }^{12}$ The ICRC had been the principal proponent and administrator of international conventions for the protection of war victims for the past century and regarded itself as having the major continuing role in the field. The Twenty-first International Conference of the Red Cross, meeting in Istanbul in 1969, requested the ICRC to take specific action including the drafting of supplementary rules and consultation with government experts on its proposals. ${ }^{13}$

The ICRC convened the first Conference of Government Experts on the Reaffirmation and Development of International Humanitarian Law Applicable in Armed Conflicts in May and June of 1971. Experts from thirty-nine countries, including the United States, participated and considered eight volumes of materials prepared by the ICRC. ${ }^{14}$ A second similar conference met for a month during May and June of 1972 in response to the invitation from the ICRC to all parties to the Geneva Conventions of 1949 for the Protection of War Victims. The conference consisted of experts from seventyseven governments and considered two draft additional protocols to the Geneva Conventions of 1949 prepared by the ICRC-one concerning international conflicts and the other concerning internal conflicts. ${ }^{15}$ On the basis of

11. G.A. Res. 2444 (XXIII), December 16, 1968, 23 U.N. GAOR Supp. (No. 18) 50, U.N. Doc. A/7218 (1968).

The U.N. General Assembly has adopted resolutions entitled Respect for Human Rights in Armed Conflicts as follows: 2444 (23d G.A.); 2597 (24th G.A.); 2674 (25th G.A.); 2676 (25th G.A.); 2677 (25th G.A.); 2852 (26th G.A.); 2853 (26th G.A.); 3032 (27th G.A.); 3102 (28th G.A.); 3319 (29th G.A.); 3500 (30th G.A.); $31 / 19$ (31st G.A.); 32/44 (32d G.A.) (1977).

12. Each of the three reports is entitled, "Respect for Human Rights in Armed Conflict." U.N. Doc. A/7720 (1969); U.N. Doc. A/8052 (1970); U.N. Doc. A/8370 (1971).

13. Resolution XIII, 104 INT'L REV. OF THE RED Cross 615, 616 (1969).

14. International Committee of the Red Cross (ICRC) Materials dated January 1971. In addition to Document I (introduction) and Document VIII (annex), the subjects covered in the documents were: implementation of existing law (Document II); civilians (Document III); combatants (Document IV); internal armed conflicts (Document V); guerrilla war (Document VI); and the wounded and sick (Document VII) [hereinafter cited as January 1971 ICRC Materials]. See also ICRC, RePORT ON THE WORK OF THE Conference of Government Experts on the Reaffirmation and Development of International Humanitarian law Applicable in Armed Conflicts (Geneva, 24 May-12 June 1971), Report on the Work of the Conference (1971) [hereinafter cited as RePort on 1971 Experts' Conference].

15. ICRC, Documentary Material, 1 Basic Texts (January 1972) [hereinafter cited as ICRC, 1 Basic Texts]. See also, ICRC, Documentary Material, 2 Commentary Part One (January 1972) (on Protocol I); ICRC, Documentary Material, 2 Commentary Part Two (January 1972) (on Protocol II); ICRC, 1 \& 2 RePort on the WORK OF THE Conference [of Government Experts, 1972] (July 1972) (the first volume is about the draft articles, and the second, about the annexes) [hereinafter cited as RePORT on 1972 EXPERTs' CONFERENCE]. 
the expression of views at the second conference, the ICRC prepared revisions of the two draft protocols ${ }^{16}$ along with a commentary on each. ${ }^{17}$

The Swiss government convened the Diplomatic Conference on the Reaffirmation and Development of International Humanitarian Law Applicable in Armed Conflicts to consider these two draft protocols.' The Conference met in four annual sessions in Geneva from 1974 through $1977 ; ;^{18}$ more than one hundred states participated in its work. By consensus at the 1974 Session of the Conference, the national liberation movements that were recognized by their respective regional international organizations were invited to participate in both committee work and in the plenary sessions on the understanding that only states were allowed to vote. ${ }^{19}$ Pursuant to this arrangement, ten liberation movements participated in the Conference. ${ }^{20}$ It was believed that this would bring about a more realistic and practical approach to the legal criteria that could be applied by irregular forces in combat situations.

Three main committees of the Conference were responsible for work on both Protocols. Committee I's major concern was the key first article, which dealt with the proposed international status of wars of national liberation; it also worked on the Preamble and the articles relating to application and execution. The work of Committee II covered the general protection of the wounded, sick, and shipwrecked, as well as the identification and protection of medical and civil defense personnel and units. Committee III was responsible, inter alia, for two related subjects: the new category of prisoners of war, and the articles concerning protection of the civilian population. In addition to the three main committees, there was a Drafting Committee, an Ad Hoc Committee on Weapons, and a Credentials Committee. This study focuses on the articles of Protocol I dealing particularly with privileged combatant status in international armed conflicts.

16. ICRC, Draft Additional Protocols to the Geneva Conventions of August 12, 1949 (1973). Draft Protocol I, id. at 3-32, is hereinafter cited as ICRC, Draft Protocol I.

17. ICRC, Draft Additional Protocols to the Geneva Conventions of August 12, 1949 : COMMENTARY (1973) [hereinafter cited as ICRC, 1973 COMMENTARY].

18. This and the following paragraphs are based upon the official documents of the Conference generally cited as CDDH (Conférence Diplomatique du Droit Humanitaire), ICRC, OfFICIAL Records of the Diplomatic Conference on the Reaffirmation and Development of International Humanitarian Law Applicable in Armed Conflicts, Geneva 1974-1977 (1978) [hereinafter cited as CDDH Official Records] and on the four Reports of the United States Delegation [to the Geneva Conference on International Humanitarian Law'] submitted by Ambassador George H. Aldrich, Chairman of the U.S. Delegation, to the Secretary of State [hereinafter each will be cited as Delegation Report, with year added].

19. 5 CDDH Offictal ReCORDS, supra note 18 , at $250(\mathrm{CDDH} / 22$ and Corr. I, adopted March $1,1974) ; i d$, at 65-70 (CDDH/SR.7).

20. The African National Congress, the Angola National Liberation Front, the Mozambique Liberation Front, the Palestine Liberation Organization, the Panafricanist Congress, the People's Movement for the Liberation of Angola, the Seychelles People's United Party, the South West African People's Organization, the Zimbabwe African National Union, and the Zimbabwe African People's Union. 
Following the action of the Diplomatic Conference on June 8, 1977, in adopting by consensus the "Protocol Additional to the Geneva Conventions of 12 August 1949, and Relating to the Protection of Victims of International Armed Conflicts (Protocol I)" and the "Protocol Additional to the Geneva Conventions of 12 August 1949, and Relating to the Protection of Victims of ${ }^{\circ}$ Non-International Armed Conflicts (Protocol II)"21 the Final Act of the Conference was signed on June 10,1977, by states and national liberation movements. ${ }^{22}$ The Protocols were signed by the representatives of more than forty states in Berne, Switzerland, on December 12, 1977, and then became available for ratification. ${ }^{23}$ Both Protocols are now treaties in force for tinree states which have ratified under Protocol I, article 93, and Protocol II, article 21, or acceded under Protocol I, article 94, and Protocol II, article 22. ${ }^{24}$

\section{II}

\section{Analysis of the Protocol I Criteria Concerning Privileged Combatants}

\section{A. Preliminary Consideration of the New Criteria for Privileged Combatant Status}

The ICRC introduced recommendations at the 1971 Conference of Government Experts that were designed to reduce the traditional Brussels-HagueGeneva criteria applicable to irregulars to qualify them for POW status upon

21. Both Protocols are in ICRC, Protocols Additional to the Geneva Conventions of 12 August 1949 (1977) [Protocol I, id. at 3, is hereinafter cited as ICRC, Protocol I]. This has been published in the six official languages of the Conference, which were Arabic, Chinese, English, French, Russian, and Spanish. The Protocols are also in 72 AM. J. INT'L L., April 1978, at 457-509 (Off. Docs.). (The Protocols are also reprinted as an appendix to this issue, 42 LAw \& Contemp. Prob., Spring 1978, at 203).

22. The Final Act, photographic reproductions of the signature pages, the Resolutions adopted in 1977, as well as both Protocols, appear in 1 CDDH Official Records, supra note 18.

23. Note from the Embassy of Switzerland to the Department of State dated January 26 , 1978.

24. The following states have deposited instruments of ratification or accession with the Swiss Federal Council, Berne:

(1) Ghana (ratification) Feb. 28, 1978

(2) Libya (accession) June 7, 1978.

Note: Pursuant to Protocol I, article 95(1), and Protocol II, article 23(1), both Protocols went into force for the above two states on Dec. 7, 1978.

(3) El Salvador (ratification) Nov. 23, 1978.

Note: Pursuant to Protocol I, article 95(2), and Protocol II, article 23(2), both Protocols went into force for El Salvador six months after the date of the deposit of the instrument of ratification.

(4) Equador (ratification) April 10, 1979.

(5) Jordan (ratification) May 1, 1979.

Note: Both Protocols will come into force for each of the above states six months after the date of deposit of ratification. 
capture. ${ }^{25}$ A number of experts supporting improved protection for irregulars thought that two of the traditional criteria-the fixed distinctive sign and the open carrying of arms-were inconsistent with the requirements of guerrilla methods of warfare. ${ }^{26}$ It was assumed that this was the principal, if not the only, type of warfare to be conducted by irregular armed forces. There was also a wide consensus that both military organization and observation of the laws and customs of war were indispensable for all armed forces, including irregulars, ${ }^{27}$ and there was a realistic recognition that it would not be possible to provide adequate protection to the noncombatant civilian population unless irregulars were distinguished from noncombatants in some meaningful way. ${ }^{28}$ Freedom of expression was facilitated at the 1971 and 1972 preliminary meetings by the understanding that governments were not bound by the views expressed by their experts.

The desirability of reduced criteria for irregulars was widely accepted at the 1972 meeting. ${ }^{29}$ This involved the recognition that irregulars could not be expected to attempt to achieve privileged status unless the criteria imposed upon them were moderate and practically attainable. Some speakers regretted that no representatives of the resistance movements that were then involved in armed struggle were participating in the meeting. ${ }^{30} \mathrm{~A}$ number of experts criticized the requirements of article $4 \mathrm{~A}(2)$ of the Geneva POW Convention as excessively rigid in the light of modern conflict realities. ${ }^{31}$ It was pointed out that making irregulars subject to capital punishment for violation of the conditions of the existing law discouraged them from observing the humanitarian law of war on their side. ${ }^{32}$ There was apparently no dissent from the basic concept that irregulars must adhere to the laws and customs of war.

\section{B. Article 1-Principles and Scope of Application}

The 1972 and 1973 ICRC drafts of article 1 provided simply that the international conflicts Protocol would apply to the situations referred to in the common article 2 of the Geneva Conventions of 1949, and left the matter of wars of national liberation, described as "armed struggle" to achieve the "right to self-determination," to the tentative paragraph 3 of draft article 42 . The situations covered by the 1949 Conventions include declared wars and other international conflicts without regard to the recognition of a so-called "state of

25. January 1971 ICRC Materials, supra note 14, Document VI, Rules Applicable in Guerrilla Warfare, at 6-23.

26. Report on 1971 Experts' Conference, supra note 14, at 68, col. 2.

27. Id.

28. Id. at 69 , col. 1 .

29. I Report on 1972 Experts' Conference, supra note 15, at 133-35.

30. Id. at 130 , col. 1 .

31. Id.

32. Id. 
war." The Conventions are also applicable to partial belligerent occupations as well as to more comprehensive ones. The ICRC Commentary on the $1973 \mathrm{draft}$ article 1 stated that some experts believed the situations referred to in the common article 2 of the 1949 Conventions should "include armed struggles waged by peoples for the exercise of their right of self-determination." 33

The tentative paragraph 3 of draft article 42 provided that "where peoples exercise their right to self-determination as guaranteed by the United Nations Charter," the "members of organized liberation movements" who comply with the three conditions of (1) operating under military command, (2) distinguishing themselves from civilians, and (3) complying with the applicable law, "shall be treated" as POWs as long as they are detained. ${ }^{34}$ Such "members" (irregulars) would thereby receive the treatment but not the status of POWs. This tentative paragraph was the ICRC response to the concerns expressed during the experts' conferences, and it led directly to article 1(4) as well as articles 43 and 44 of the final text of Protocol $I$.

Committee I was responsible for determining the type of armed conflicts covered by Protocol I and for redefining the scope of application of the Geneva Conventions of 1949. During the first session of the Diplomatic Conference, the subject of wars of national liberation dominated the work of the Committee. Fifty-one states submitted a draft amendment to the ICRC draft of article $1 .{ }^{35}$ The effect of the amendment was to make the law concerning international conflicts applicable to conflicts fought for self-determination against alien occupation and against colonialist and racist regimes. ${ }^{36}$ The arguments in favor of the proposal were that it was justified by the decolonization provisions of the United Nations Charter and by resolutions of the General Assembly-particularly the resolution entitled "Declaration on Principles of International Law Concerning Friendly Relations and Cooperation Among States in Accordance with the Charter of the United Nations." ${ }^{37}$ The view was that if people were denied their right to selfdetermination, it would be lawful for them to assert this right through the use of force, and that such conflicts should be treated accurately as international ones governed both by the draft Protocol I and by the Geneva Conventions of 1949. The basic response from the United States and other opponents was that this was an attempt to introduce the discredited "just war" theory into what has been and should be an impartial and nondiscriminatory humani-

\footnotetext{
33. ICRC, 1973 CommentaRY, supra note 17, at 6.

34. ICRC, Draft Protocol 1, supra note 16, at 14.

35. $8 \mathrm{CDDH}$ Official Records, supra note 18 , at 8 (CDDH/L/SR.2).

36. For the text of the amendment, see $i d$. at 7 (CDDH/48/Rev. 1$)$.

37. G.A. Res. 2625 (XXV), October 24, 1970, 25 U.N. GAOR Supp. (No. 28) 121, U.N. Doc. A/8028 (1970). See statement of Professor Abi-Saab of Egypt in introducing the proposed amendment in 8 CDDH OfFICIAL Records, supra note 18, at 8 (CDDH/L/SR.2).
} 
tarian law. ${ }^{38}$ In reply it was argued that the scope given to "international" armed conflicts in the Geneva Conventions of 1949 was discriminatory and embodied a "just war" theory that viewed only wars between European powers as international ones. In response to the charge of politicalization of the law, it was pointed out that Western states had traditionally used the humanitarian law to promote their own political position. For example, after the conclusion of the Franco-Prussian War, franc-tireurs and the levée en mass were given legal recognition by the European community of states, first in the Brussels Declaration of $1874^{39}$ and then in the Hague Conventions of $1899^{40}$ and 1907.41 In rejoinder to arguments by the Western powers that national liberation movements did not have the means to comply with the international law of armed conflict, including the detailed provisions of the Geneva Conventions of 1949, it was claimed that the Western powers had themselves committed massive violations of the law and were in no position to argue possible future violations by national liberation movements. The debate proceeded in an atmosphere of confrontation, and when the vote was taken in Committee I, the proposed text was adopted by seventy votes to twenty-one, with thirteen abstentions. ${ }^{42}$

At the final sessions in 1974, the Plenary adopted a resolution by consensus, which accepted the report of Committee I and welcomed the adoption of draft article 1 by Committee I. ${ }^{43}$ The exact text of draft article 1(2) was ultimately adopted by the Conference Plenary in 1977 as article 1(4). It provides:

The situations referred to in the preceding paragraph include armed conflicts in which peoples are fighting against colonial domination and alien occupation and against racist regimes in the exercise of their right of selfdetermination as enshrined in the Charter of the United Nations and the Declaration on Principles of International Law concerning Friendly Relations and Co-operation among States in accordance with the Charter of the United Nations.

As adopted by the Plenary in 1977, paragraph 1 of article 1 paraphrases the obligations set forth in the common article 1 of the 1949 Conventions to "respect and ensure respect" for the present Protocol. Paragraph 2 is a restatement of the famous DeMartens clause providing that in situations not

38. The contending views summarized in the textual paragraph appear in the Summary Records of the First Committee at the First Session of the Conferencce, 8 CDDH OfFicial. Records, supra note 18, at 7-13 (CDDH/I/SR.2-14).

39. Brussels Declaration, supra note 1 , at arts. $9,10$.

40. Hague Convention No. II With Respect to the Laws and Customs of War on Land (and Annexed Regulations), July 29, 1899, [1902] 32 Stat. 1803, T.S. No. 403, 2 Malloy, Treaties 2042, Annexed Regulations, at arts. 1, 2 [hereinafter cited as Hague Convention II of 1899].

41. Hague Convention IV of 1907, supra note 1, Regulations Annexed, at arts. I \& 2, 2 Malloy, Treaties 2269, at 2281.

42. 10 CDDH OfFicial. Records, supra note 18, at 6-7 (CDDH/48/Rev.1); 8 CDDH OfFicial RECORDS, supra note 18, at 102 (CDDH/I/SR.13).

43. 5 CDDH Official ReCords, supra note 18, at 225, 227 (CDDH/SR.22). 
covered by treaty law both civilians and combatants "remain under the protection and authority of the principles of international law derived from established custom, from the principles of humanity and from the dictates of public conscience." Paragraph 3 incorporates by reference the international conflict situations referred to in the common article 2 of the 1949 Conventions. It is these situations which are now redefined by paragraph 4 to include conflict situations concerning colonial domination and alien occupation and against racist regimes (CAR conflicts). ${ }^{44}$

The task of ascertaining the more precise meaning of this paragraph concerning wars of national liberation remained before the Conference; the subsequent negotiating position of the Western states was that other provisions of Protocol I had to take into account the draft provisions of article 1 so that the obligations that were involved would be applied in a nondiscriminatory manner. ${ }^{45}$ This led to the adoption of nondiscriminatory provisions both in the Preamble and in article 96. The final paragraph of the Preamble provides that the Protocol must be applied to all protected persons "without any adverse distinction based on the nature or origin of the armed conflict or on the causes espoused by or attributed to the Parties to the conflict." This is of particular importance to the United States because of the claim by the Democratic Republic of Vietnam during the Southeast Asia conflict that U.S. armed services personnel, especially aviators, were not entitled to POW status upon capture because the United States was alleged to be engaged in a war of aggression. Article $96(3)$ provides a method for a nonstate party, termed an "authority representing a people," engaged in a CAR conflict to deposit a declaration bringing the 1949 Conventions and Protocol $I$ into effect for itself. This article specifically provides that "the Conventions and this Protocol are equally binding upon all Parties to the Conflict."46 These changes were brought about in considerable measure through the skilled and patient efforts of a number of delegations, including that of the United States, in an atmosphere quite opposite to the confrontation situation that prevailed in Committee $I$ in the 1974 session. As a result of these changes, there was a drastic diminution of Western opposition to article 1. The satisfaction of the United States Delegation at the adoption of article $96(3)$ is recorded in these words:

44. For convenience, the conflict situations concerning "colonial domination and alien occupation and against racist regimes" will be referred to as "CAR conflicts," and the regimes involved, as "CAR regimes." For a discussion of the DeMartens clause, see Commentary, IV Geneva Convention Relative to the Protection of Civilian Persons in Time of War 626 (J. Pictet ed. 1958).

45. Delegation Report, supra note 18, at 7, 31-33 (1977).

46. ICRC, Protocol I, supra note 21 , at art. 96(3)(c). This provision is subject to art. 96(2), which refers to parties to the conflict (state parties and authorities) that are not bound by the Protocol. Article 96(3)(b) states that "the said authority assumes the same rights and obligations as those which have been assumed by a High Contracting Party to the Conventions and this Protocol." 
In view of the fact that Article 1 established that wars of national liberation are to be considered international armed conflicts, it was important to add this provision on declarations to make clear that there would be no discrimination in favor of liberation movements, that they could not have rights without the corresponding obligations, and that the laws of armed conflict would have to be fully applied by those movements. ${ }^{47}$

The comprehensive wording of article 96(3), providing for the application of Protocol I and all four of the 1949 Conventions to authorities representing a people (national liberation movements), has remained unchanged in spite of the privately expressed views of delegates that such complete application is not possible. It must be acknowledged that it is beyond the realm of reasonableness to expect such authorities or movements to apply all of the detailed rules concerning the treatment of POWs in the 1949 POW Convention, which are predicated upon the existence of governmental institutions of the captor. ${ }^{48}$ In the same way, it is equally unreasonable to expect such authorities to apply the elaborate prescriptions of the 1949 Civilians Convention, which are based upon the existence of a governmental belligerent occupant with effective control over territory and civilian persons. ${ }^{49}$ The wording of article 96(3), nevertheless, appears to prescribe mutuality and reciprocity in the obligations undertaken by authorities and states in spite of their different characteristics and capabilities. The ensuing dilemma may be substantially mitigated, if not resolved, by interpreting provisions of the type just referred to in the text in a commonsense manner so as not to impose obligations that are impossible to fulfill. While this would impinge upon the theoretical balance of exact mutuality and reciprocity, it would leave much that could be enforced. It is far better to have some law that can be enforced in a conflict than to impose impossible obligations upon one of the parties involved with the result that little or no humanitarian law will be applied. The Protocol and the Conventions embody a substantial number of fundamental humanitarian rules and principles that can be observed by irregulars as well as regulars. Both are able to respect and protect wounded, sick, and shipwrecked combatants along with POWs and civilians. The fact that one party to a CAR conflict has a governmental structure provides no guarantee that it will adhere to the humanitarian rules; that the opposing party lacks such a structure does not prevent it from adhering to the same rules. ${ }^{50}$

47. Delegation Report, supra note 18, at 7 (1977).

48. E.g., POW Convention, supra note 1, at arts. 82-108 (pt. III, ch. III, Penal and Disciplinary Sanctions), U.S.T. 3382-3400.

49. E.g., Civilians Convention, supra note 5, at arts. 47-78 (pt. III, sec. III, Occupied Territories), U.S.T. 3548-3568.

50. The points made in the text also appear in Bond, Amended Article 1 of Draft Protocol I to the 1949 Geneva Conventions: The Coming of Age of the Guerrilla, 32 WASH. \& LeE L. Rev. 65, 76-77 (1975). 
On May 23, 1977, the Plenary considered article 1. Mr. Hess of the State of Israel stated that his delegation accepted the first three paragraphs of the. article but insisted on a separate vote on the fourth paragraph. ${ }^{51}$ The motion for a separate vote was defeated, and Ambassador Aldrich of the United States asked if article 1 could now be adopted by consensus. ${ }^{52} \mathrm{Mr}$. Hess asked for a vote on article 1 as a whole, and the Algerian and Egyptian representatives asked for a roll call vote. ${ }^{53}$ The outcome was eighty-seven in favor, one against (Israel), and eleven abstentions (including the United States). ${ }^{\mathbf{5 4}}$

That the language used in article l(4) was designed to cover "wars of national liberation" was not disputed, although this term was not used. The reason given for the use of the term "right of self-determination" was that this was an accepted legal concept of the United Nations Charter. ${ }^{55}$ This phrase had been used in the General Assembly's 1970 resolution on international law and friendly relations. ${ }^{56}$ It was also used in the 1973 resolution of the General Assembly entitled "Basic Principles of the Legal Status of the Combatants Struggling against Colonial and Alien Domination and Racist Regimes."57 This resolution, which influenced the subsequent wording of article 1(4) of the Protocol, provides that armed conflicts by peoples against CAR regimes are international armed conflicts within the meaning of the 1949 Geneva Conventions and that the legal status applicable to combatants in those conventions is to apply to the persons engaged in such armed struggle. It is also provided explicitly that such combatants are to be accorded POW status under the terms of the 1949 POW Convention. The resolution thereby declares the international status of CAR conflicts, but it does not reduce the four traditional Brussels-Hague-Geneva criteria that combatants must meet to qualify for the privileged status of POWs upon capture. ${ }^{58}$

The scope of CAR conflicts covered by article 1(4) may be interpreted broadly or narrowly. If interpreted broadly, the words "colonial," "alien," and "racist" may be merely illustrative of wars fought for self-determination, and all conflicts with this objective would be covered. Nevertheless, a wide consensus developed among those strongly favoring the provision to interpret it nar-

51. 6 CDDH Official Records, supra note 18, at 39 (CDDH/SR.36). The Summary Records of the 1977 plenary meetings are in two volumes (6 \& 7 CDDH OfFICIAL Records, supra note 18). The first covers the 34th to 46th meetings (March 17, 1977 to May 31, 1977); the second covers the 47 th to 59 th meetings (May 31, 1977, to June 10, 1977).

52. 6 CDDH Official Records, supra note 18 , at 40 .

53. Id.

54. Id. at 41 .

55. See, e.g., the explanations of vote by Mr. Gribanov (U.S.S.R.), id., at 42-43, and Professor Abi-Saab (Egypt), id., at 43-44.

56. Supra note 37 .

57. G.A. Res. 3103 (XXVIII), December 12, 1973, 28 U.N. GAOR Supp. (No. 30) 142, U.N. Doc. A/9030 (1973).

58. See text accompanying note 1 supra. 
rowly. The consensus was that CAR conflicts were fought against alien and colonial armies and not against local forces. ${ }^{59}$ Unless this approach to interpretation is accepted, there seems to be little justification for Protocol II concerning internal conflicts. Ambassador Clark of Nigeria provided a good example of what is meant by a war of national liberation: "He understood the right to self-determination not as encouraging secessional and divisive subversion in multi-ethnic nations, but as applying to a struggle against colonial and alien domination, foreign occupation and racist regimes." ${ }_{0}$ This African view reflects the concern of many of the third world states that CAR conflicts could be misinterpreted as encouraging secessionist movements within existing national states.

The term "alien occupation" requires some special consideration. It does not refer to traditional military occupations of the type covered by the Geneva Civilians Convention of 1949. Many speakers gave it a meaning basically equivalent to colonial occupation. ${ }^{61}$ This is the meaning used by the United Nations resolution on the claimed illegal occupation of Mozambique by Portugal as it existed in $1974 .{ }^{62}$ A contemporary example of alien occupation that would be accepted without qualification by the third world, and by many of the Western states as well, would be the South African presence in Namibia (the former Southwest African Mandated Territory).

In summary, the negotiating history has given the CAR conflicts a narrow meaning. In one respect, however, the meaning is somewhat broader than the text would suggest. The text uses the word "and" between the words "colonial," "alien," and "racist." However, it is the understanding of those who spoke on the matter that every CAR conflict does not have to be against an adversary that has the characteristics of all three of these terms: a conflict that, inter alia, meets any one of the three criteria qualifies. The irregulars fighting against the CAR regime thus are protected by Protocol I. For example, the situations in Southern Africa are considered to be racist, although not necessarily colonial, and consequently are deemed to be CAR conflicts. The Palestinian situation, as stated by Mr. Armali of the Palestine Liberation Organization during the explanations of vote on article 1 , is quite different, as the PLO regards the State of Israel as falling within all three of the named categories. ${ }^{63}$

Recognition of national liberation movements should also be a key factor in achieving a narrow interpretation of the scope of CAR conflicts. The action

59. See the comments of Professor Abi-Saab (Egypt), $8 \mathrm{CDDH}$ Ofricial Records, supra note 18 , at 33-35 (CDDH/L/SR.5).

60. Id. at $12,13(\mathrm{CDDH} / \mathrm{l} / \mathrm{SR} .2)$.

61. See, e.g., comment of Mr. Khattabi (Morocco), 8 CDDH Official Recorns, supra note 18, at $19(\mathrm{CDDH} / \mathrm{I} / \mathrm{SR} .3)$.

62. G.A. Res. 3061 (XXVIII), 28 U.N. GAOR Supp. (No. 30), U.N. Doc. A/9030 (1973).

63. 6 CDDH Official Records, supra note 18, at 33, 53 (CDDH/SR.36). 
of the Diplomatic Conference in inviting only those national liberation movements that were recognized by their respective regional intergovernmental organizations ${ }^{64}$ was treated as a relevant precedent. Several speakers said that only genuine liberation movements were included within the scope of article $1(4)$, and these were the ones so recognized. ${ }^{65}$

It should also be mentioned that CAR conflicts are characterized as "armed conflicts," which must reach a certain level of intensity. ${ }^{66}$ Riots and analagous acts of violence on an isolated basis do not qualify as armed conflicts. In addition, articles 43 and 44 make it clear that the combatants fighting CAR regimes must meet the requirements of organization, discipline, and adherence to the law, which are quite beyond the objectives and capabilities of criminals.

When Protocol I goes into effect it will not have retrospective application. It is interesting, nevertheless, to examine its theoretical application to the American Revolution of two centuries ago. If it is postulated that the basic facts of the American Revolution were to occur today, it is widely believed that the rebelling colonists would not be entitled to POW status under article 4 of the Geneva POW Convention. They would, however, be legally entitled to at least the minimum standards prescribed by the common article 3 in the Geneva Conventions of 1949 concerning civil wars. Under the existing law, if these assumptions are accepted, the American colonists in revolt would not only fail to achieve POW status, but could also be tried for various crimes under municipal law, including the crime of murder for killing British soldiers. (In the actual event, as is well known, the British Government did not exercise its legal authority to treat revolutionaries as common criminals.) If, however, it is assumed that Great Britain did not deny that it was a colonial regime, and that the American revolutionaries made a declaration under article 96, Protocol I would apply, and the legal situation would be clear and unambiguous with the American revolutionary armed forces having the status of privileged combatants. Under article 1(4) the Americans would be a people fighting for the right of self-determination against, to use the precise words, "colonial domination." From a third world perspective, contemporary conflicts directed against CAR regimes are substantially the same type of conflict that was exemplified by the classic American Revolution. The human rights at stake in this type of conflict were regarded as so important by the Diplomatic Conference that they must be brought within the scope of Protocol I.

In addition to the foregoing appraisal of the scope of article 1(4), it is es-

64. Supra note 19.

65. See, e.g., the statements of the delegates of Indonesia, Oman, and Zaire, 9 CDDH OFFICIAL Records, supra note 18, at 369, 370,375 (CDDH/I/SR.68).

66. See the "general point of interpretation" made by $\mathrm{Mr}$. Freeland (United Kingdom), 6 CDDH OfFICIAL ReCoRds, supra note 18, at 33, 47 (CDDH/SR.36). 
sential to examine the same provision in terms of the degree of probability of its application in contemporary and future CAR conflicts. It should be recalled that classifying a conflict as a CAR does not automatically accord privileged combatant status to the armed forces of the peoples fighting against CAR regimes. In order to achieve this status, such combatants must also meet the criteria of articles 43, 44, and 96 of Protocol I. In addition, the violence must reach a level sufficient to qualify the coercion situation as an armed conflict.

Assuming that a conflict may be objectively classified as a CAR, a dilemma remains: state-parties to Protocol I could simply deny that they were CAR regimes, since there is no provision for impartial determination of this status by a third party. The terminology of article $1(4)$ has been described as containing a "built-in non-applicability clause." ${ }^{67}$ A state that conceded the applicability of article 1(4) would be accepting the contention of its enemy. Because of these considerations, it does appear that it would be difficult to enforce article 1(4) against CAR regimes as a matter of treaty law, at least in the near future.

There seem also to be substantial difficulties in applying the substance of article 1(4) to CAR regimes, on the basis that this provision has become accepted as customary law. Article $1(4)$ is widely regarded as a law-making rather than a law-declaratory provision. In addition, to the extent that customary law is based on state practice, there seems to be little directly relevant state practice that can be relied upon. Nevertheless, the power of the word, enunciated as authoritative legal doctrine, should not be underestimated. If Protocol I becomes a widely ratified multilateral convention, and the major military powers are included among the state-parties, there is strong reason to believe that article 1(4) will be accepted as prescribing a standard or norm in international law. States that flout the standard should expect to be subjected to political as well as other forms of sanctions, even if article 1(4) cannot be applied to them immediately as a matter of law. Over a period of time, the treaty standard, which has been prescribed, may well be enforced as law. ${ }^{68}$

67. In the 1977 Plenary, following the roll call vote adopting article 1 , Mr. Hess (Israel) expressed concern about claimed politicalization of the law and stated that a rule intended to apply to one type of combatant was not a legal norm. Hess continued:

Secondly, draft Article 1, paragraph 4 had within it a built-in non-applicability clause,

since a party would have to admit that it was either racist, alien or colonial-definitions

which no State would ever admit to. By including such language, the Conference had, to

his regret, ensured that no State by its own volition would ever apply that article.

6 CDDH Official Records, supra note 18, at 33, 42 (CDDH/SR.36).

68. The Brussels Declaration of 1874 , supra note 1 , provides a different example of ultimate enforcement of a legal norm even though the Declaration remained unratified. Its article 9 accorded privileged combatant status for irregulars of the same type as those who were executed as franc-tireurs by the Prussian Government during the Franco-Prussian War. The Declaration first 


\section{Article 43-Armed Forces}

The ICRC's 1972 and 1973 drafts of this article were both entitled "organization and discipline." The 1972 version (numbered 39) simply provided that armed forces shall be organized and subject to an internal discipline system, which should enforce respect for the applicable rules of international law. ${ }^{69}$ The 1973 version (numbered 41) varied the text so that the term "armed forces" included "the armed forces of resistance movements."70

During the 1976 session of the Conference, Committee III expanded the ICRC draft of article 41 in several respects and adopted this article (which ultimately became article 43 ) by consensus. ${ }^{71}$ The article adopted by the Committee at that time is in all textual particulars except one identical with the text the Conference Plenary adopted by consensus on May 25, 1977.72 The only difference is that the first paragraph of the draft text included a third sentence defining the applicable rules of international law, which is now included in article 2 on definitions.

The key first sentence of article $43(1)$ provides:

The armed forces of a Party to the conflict consist of all organized armed forces, groups and units which are under a command responsible to that Party for the conduct of its subordinates, even if that Party is represented by a government or an authority not recognized by an adverse party.

The breadth of the conception of the "armed forces of a Party to a conflict" is emphasized by bringing even forces of a party that is represented by an unrecognized government or authority within the definition. This is not a novel conception, since article $4 \mathrm{~A}(3)$ of the Geneva POW Convention ${ }^{73}$ accords privileged status to regulars represented by an unrecognized government or authority. The comprehensive word "authority" refers to nongovernmental public bodies engaged in resistance to belligerent occupations and participation in CAR conflicts. Article 43, taken with article 1(4) of Protocol I, makes it clear that national liberation movements are parties to the conflict themselves and need not be associated with a state party to the conflict in order for their military personnel to be accorded combatant status as "armed forces." This is an improvement over the somewhat less explicit wording concerning organized resistance movements in article $4 \mathrm{~A}(2)$ of the Geneva POW

\footnotetext{
received wide assent as customary law in spite of Prussian opposition, and it was thereafter written into Hague Convention II of 1899, supra note 40, and Hague Convention IV of 1907, supra note 1 , as article 1 . The same substantive provision was written into the Geneva POW Convention as article $4 \mathrm{~A}(2)$. POW Convention, supra note 1 , at art. $4 \mathrm{~A}(2)$.

69. ICRC, 1 Basic Texts, supra note 15 , at 15.

70. ICRC, Draft Protocol I, supra note 16, at 13 .

71. 15 CDDH Official RecoRds, supra note 18, at 85, 91 (CDDH/III/SR.47).

72. 6 CDDH Official Records, supra note 18, at 93, 111 (CDDH/SR.39).

73. POW Convention, supra note 1 , at art. $4 A(3), 6$ U.S.T. 3316 , at 3320.
} 
Convention. ${ }^{74}$ It is significant that the present article makes no juridical distinction between regulars and irregulars. Both groups are privileged combatants entitled to participate in hostilities, although the word "privileged" is not used.

The second sentence of paragraph 1 requires that such armed forces be subject to an internal disciplinary system, which shall enforce compliance with the applicable rules of international law. Article 1 of Hague Convention IV of $1907^{75}$ requires state-parties to issue instructions to their armies in conformity with the Annexed Regulations. The provision in paragraph 1 of article 43 imposes an analogous educational responsibility upon irregulars along with regulars. This article places appropriate emphasis upon military discipline and adherence to international law. Discipline is highly desirable for military efficiency as well as essential to observance of law. While this article promotes observance of the law, it does not make such observance a requirement for inclusion as "armed forces."

The second paragraph expressly provides that members of the armed forces of a party to the conflict (except medical personnel and chaplains) are combatants, who have the right to participate directly in hostilities. This is an improvement over article 4 of the Geneva POW Convention, which by implication makes the criteria for POW status also the criteria for privileged combatant status. This new second paragraph also promotes clarity by denying, by necessary implication, privileged combatant status to those who are not members of the armed forces under the definition of the first sentence of the article.

The third paragraph allows a state to incorporate a paramilitary police force into its armed forces; conditional upon the requirement of notice to other parties to the conflict. This is a practical provision, since a number of states have paramilitary type police forces.

\section{Article 44-Combatants and Prisoners of War}

The 1972 ICRC draft article entitled "Guerrilla fighters" (and numbered 38) provided that "members of militias or volunteer corps," including members of "organized resistance or independence movements," were entitled to POW status upon capture, even if represented by an unrecognized government or authority. ${ }^{76}$ It was added that they must fulfill the following conditions: (a) comply with applicable law; (b) distinguish themselves from the civilian population by carrying arms openly or by wearing a fixed distinctive sign "or by any other means"; and (c) be organized under a responsible commander.

74. See Mallison \& Mallison, supra note 2, concerning the organized resistance movement as its own party to the conflict under art. $4 \mathrm{~A}(2)$.

75. Hague Convention IV of 1907, supra note 1, 2 Malloy, Treaties 2269, at 2277.

76. ICRC, I BASIC TExTs, supra note 15, at 14-15. 
The ICRC's 1973 draft article entitled "New category of prisoners of war" (and numbered 42) provided the same three criteria that appeared in the $1972 \mathrm{draft}$, with minor changes in wording. ${ }^{77}$ The requirement of adherence to law was specified as "conduct their military operations in accordance with the Conventions [of 1949] and the present Protocol." 78 This requirement should be interpreted in a realistic manner, so that it imposes the fundamental obligations of the 1949 Conventions on organized resistance movements. The draft provision of paragraph 1 concerning parties to the conflict represented by unrecognized governments or authorities appears now in the adopted article 43 rather than in article 44.

Paragraph 1 of the adopted article 44 states that any combatant "as defined in article 43" shall be deemed a prisoner of war upon capture. Paragraph 2 restates the article 43 obligation of all combatants to comply with the international law applicable in armed conflict and adds that compliance with these rules is not a condition for entitlement to combatant or POW status. The only exceptions where violations of international law do deprive a combatant of his right to such privileged status are provided in paragraphs 3 and 4.

In paragraph 3, the first sentence states explicitly the relationship between the requirement of distinguishing combatants from the civilian population and the objective of protecting the civilian population from the effects of hostilities. This connection has long been recognized as a practical matter, and it is highly desirable to specify it in the text of a multilateral treaty. This sentence also recognizes that combatants need only distinguish themselves from the civilian population "while they are engaged in an attack or in a military operation preparatory to an attack."

The overriding significance of the first sentence of article $44(3)$ is that it provides a new basic norm for combatants in situations where they are deemed to be able to distinguish themselves from civilians. It must be read in the light of the four well-known Brussels-Hague-Geneva requirements of (1) command, (2) distinctive sign, (3) open arms, and (4) compliance with law. ${ }^{79}$ Article 43(1), considered above, repeats the requirements of military command and compliance with law (the latter is also repeated in article 44(2)) but does not mention the fixed distinctive sign or carrying of arms openly. The basic norm of the first sentence of article 44(3) also omits reference to the last two traditional criteria just mentioned. In lieu of these, it specifies an obligation ("combatants are obliged") upon combatants to distinguish themselves in some functional manner from the civilian population. Since the next sentence specifies that arms must be carried openly in exceptional circumstances where

77. ICRC, Draft Protocol 1, supra note 16, at 13-14.

78. Id. at article 42, para. 1(c).

79. See text accompanying note l supra. 
a combatant cannot so distinguish himself, it is a fair inference that a combatant must carry arms openly in the norm of the first sentence. It is also a fair inference that the combatant must do something more in the situation assumed to be typical or usual, covered in sentence one. If the additional measure of distinction is a fixed distinctive sign, the combatant has complied with article 4 of the Geneva POW Convention and with article 44(6) of Protocol I. If his additional method of distinction is almost anything more than bearing arms openly, he has probably complied with the functional but unspecified criteria of the first sentence of article 44(3) for distinguishing combatants from civilians. If he has not met the criteria for distinction, he has violated this obligation. Thus the first sentence of article $44(3)$ retains the first, third, and fourth of the Brussels-Hague-Geneva criteria. The second criterion of the fixed distinctive sign remains available on an optional basis: if it is not employed, some functional substitute for it must be used.

The second sentence of paragraph 3 is of crucial importance where the facts do not fit into the "basic norm" of the first sentence. It recognizes that there are practical situations in armed conflicts where, "owing to the nature of the hostilities, an armed combatant cannot so distinguish himself." In such situations, he shall retain his status as a combatant along with entitlement to POW status, provided that he carries his arms openly (a) "during each military engagement" and (b) "during the time while he is visible to the adversary while he is engaged in a military deployment preceding the launching of an attack in which he is to participate."

The scope of situations where a combatant cannot distinguish himself from the civilian population may be construed either broadly or narrowly. The CAR conflicts present a fact situation in which it is not usually possible for a combatant to distinguish himself from the civilian population according to the traditional criteria that involve both a fixed distinctive sign and open carrying of arms. In addition, military operations against the belligerent occupant in occupied territory should also be included, whether or not the occupation is regarded as an "alien" one. One of the reasons for the present change in the law has been the widespread awareness of the unreality of article $4 \mathrm{~A}(2)$ of the Geneva POW Convention, which permits operations by organized resistance movements and other units within occupied territory but maintains the four traditional criteria first enunciated in the Brussels Declaration. The negotiating history of the article indicates that concern about the inadequacy of the existing law was not limited to third world states and national liberation movements. For example, Mr. Girard of the French delegation voiced this concern in Committee III during the second session of the Conference:

There is another category which interests us greatly, namely the underground fighters. They are organized into "networks" but their characteristic is that precisely nothing distinguishes them and must not distinguish them from the 
civilian population... We cannot disregard the resistance fighter and I speak of interstate conflicts-the civilian who refuses to agree to the occupation of his country by a foreign army-by approving an Article 42 which would exclude such resistance fighters and place them outside the law. ${ }^{80}$

In what circumstances must a combatant carry his arms openly in order to comply with paragraph 3(b)? The wide diversity of views on this issue is summarized in the 1977 report of Committee III:

The one question on which the explanations of vote [in Committee III] revealed a clear difference of opinion was the meaning of the term "deployment." Some delegations stated that they understood it as meaning any movement toward a place from which an attack was to be launched. Other delegations stated that it included only a final movement to firing positions. Several delegations stated that they understood it as covering only the moments immediately prior to an attack. ${ }^{81}$

A similar diversity of views was manifest in the Plenary following the roll call vote on May 26, 1977, where the article was adopted by seventy-three votes in favor (including the United States), and one against (Israel), with twenty-one abstentions. ${ }^{82}$

Mrs. Lapidoth of Israel stated:

In the view of her Government, prisoner-of-war status depended on two essential conditions: first, respect for the rules of international law applicable in armed conflicts (for the members of regular forces there was a praesumptio juris et de jure that the condition had been met); secondly, a clear and unmistakable distinction between the combatants and the civilian population. They were two sine qua non conditions established in international custom and in numerous instruments. ${ }^{83}$

Professor Al Ghunaimi of Egypt maintained that the civilian population was jeopardized primarily by foreign oppression and added that:

In his delegation's view, the expression "military deployment" meant the last step when the combatants were taking their firing positions just before the commencement of hostilities; a guerrilla should carry his arms openly only when within range of the natural vision of his adversary ${ }^{84}$

Mr. Armali of the PLO expressed a similar position:

The requirements in paragraph 3 (a) and (b) regarding the open carriage of arms could only be interpreted in the most restrictive manner: the phrase "during such time as he is visible to the adversary" must be interpreted as meaning "visible to the naked eye." ${ }^{85}$

80. 14 CDDH Official Records, supra note 18, at 537, 538 (CDDH/III/SR.33-SR.36, Annex).

81. 15 CDDH Official Records, supra note 18, at 445, 453 (CDDH/407/Rev.l).

82. 6 CDDH Official Records, supra note 18, at 119, 121 (CDDH/SR.40).

83. Id. at 121,122 .

84. Id. at 144,145 .

85. Id. at 147 . 
In Mr. Armali's view, the Israeli concerns for the civilian population were not persuasive, since the Government of Israel persistently refused to apply the Geneva Civilians Convention in occupied territory. ${ }^{86}$

Ambassador Aldrich of the United States contended:

The basic rule contained in the first sentence of paragraph 3 meant that throughout their military operations combatants must distinguish themselves in a clearly recognized manner. . .

As regards the second sentence of paragraph 3, it was the understanding of his delegation that situations in which combatants could not distinguish themselves throughout their military operations could exist only in the exceptional circumstances of territory occupied by the adversary or in those armed conflicts described in Article 1, paragraph 4, of draft Protocol I. . .

As regards the phrase "military deployment preceding the launching of an attack", in paragraph 3 , his delegation understood it to mean any movement towards a place from which an attack was to be launched. ${ }^{87}$

At the time of signing the Protocols, the United States entered an "understanding" concerning the meaning of the second sentence of paragraph 3 in words identical to those used by Ambassador Aldrich. ${ }^{88}$

In attempting an interpretation, it should be recalled that a central purpose of article 44 is to permit combatants to retain privileged status in certain factual situations, providing that they adhere to the prescribed minimum criteria that are deemed to be adequate to protect the civilian population. The factual situations referred to by Ambassador Aldrich were limited to occupied territory and CAR conflicts. There appears to be no persuasive reason to go beyond these "exceptional" situations.

The phrase in the second sentence of paragraph 3 that requires the combatant to carry arms openly "during such time as he is visible to the adversary while he is engaged in a military deployment preceding the launching of an attack" does contain a degree of precision. The concept of visibility to the adversary seems most likely to refer to natural visibility by eye, since electronic or special means are not indicated. Because of these considerations, Ambassador Aldrich's interpretation as "any movement towards a place from which an attack was to be launched" seems to be too comprehensive and could defeat the basic purpose of the article. Professor Al Ghunaimi's interpretation appears consistent with the text as well as with the preeminent policy objective of providing a practical means for combatants to retain their privileged status in exceptionally difficult circumstances. The value judgment implicit in the second sentence of paragraph 3 is that its minimal rules can be met in even very difficult combat circumstances. The hard fact is that minimal rules that can be enforced in combat situations are more effective in protecting human values than are optimal rules that have little or no chance of enforcement.

86. Id.

87. Id. at 149,150 .

88. Note from Embassy of Switzerland to the Department of State, supra note 23. 
The general sanction applicable in the article 44(3) situation for the failure of a combatant to carry his arms openly when he cannot otherwise distinguish himself from the civilian population is the possibility of trial and punishment for violation of the laws of armed conflict. Article 44(4) also specifies the additional sanction that the combatant that has failed to meet the criteria of paragraph 3 is deprived of his right to be a prisoner of war. Even in this situation he shall "be given protections equivalent in all respects to those accorded to prisoners of war." This means that although they are not POWs they shall have the benefit of the same procedural and substantive protections that are provided for POWs in the Geneva POW Convention. The 1977 Report of Committee III provides a summary of the applicable sanction:

\begin{abstract}
With one narrow exception, the article makes the sanction for failure by a guerrilla to distinguish himself when required to do so to be merely trial and punishment for violation of the laws of war, not loss of combatant or prisoner-of-war status. The exception, which was the most difficult part of the article to negotiate, related to the guerrilla fighter who relied on his civilian attire and lack of distinction to take advantage of his adversary in preparing and launching an attack. ... In that extreme case, but in that case only, the sanction for failure to comply with the requirement of distinction is that the individual may be tried and punished for any crimes he has committed as a belligerent without privileges. Even then he must be given treatment in captivity equivalent in all respects to that to which prisoners of war are entitled. ${ }^{89}$
\end{abstract}

Article 44(5) indicates that the captor may not punish those who are entitled to POW status for their "prior activities." This paragraph limits the ability of the captor to deny POW status, except in the situation where the captured person is failing to meet the criteria at the time of his capture. Paragraph 6 allows "any person" (combatants or the particular civilians enumerated in article 4 of the 1949 POW Convention) to qualify for POW status under that Convention. Paragraph 7 states that there is no intention to change the usual or "generally accepted" practice by state-parties to the conflict concerning the wearing of the uniform by combatants "assigned to the regular, uniformed armed units." This raises a significant issue: In what circumstances may regulars who are not assigned at the time to one of the "regular, uniformed armed units" qualify for POW status by meeting the reduced criteria that are applicable under article 44(3) in certain fact situations and for limited time periods? In view of the broad language of paragraph 3 , which deals with "combatants" rather than with "irregulars" or with "regulars," the regular may qualify for POW status in the same exceptional circumstances and for the same limited time in which an irregular may qualify. Had a distinction between a regular and an irregular combatant been placed in paragraph 3 , it would be unworkable as well as unjust where regulars are serving as advisers

89. Supra note 81 . 
to or commanders in an irregular force.$^{90}$ In this situation, regulars have the same right to comply with article $44(3)$ as do the irregulars with whom they are serving. Regulars are entitled to meet the minimum requirements of article $44(3)$ in other situations as well-including those where they are conducting guerrilla warfare in enemy-occupied territory.

Paragraph 8 broadens the scope of protected persons beyond the wounded and sick armed forces in the field and the wounded, sick, and shipwrecked members of armed forces at sea, which presently are enunciated in article 13 of the First and Second Geneva Conventions of 1949.91 The new and broader scope is effectuated by incorporating by reference the comprehensive conception of armed forces enunciated in article 43 of the Protocol. Such war victims now include the armed forces of a party to the conflict without regard to recognition by an adverse party.

\section{III}

Summary of Protocol I Categories of Persons Who Do Not Qualify as Privileged Combatants

\section{A. Unprivileged Combatants-Spies}

Article 46 of Protocol I (formerly article 40) entitled "Spies" does not purport to change the basic definition of a spy in article 29 of the Hague Convention IV Annexed Regulations, ${ }^{92}$ which provides that "[a] person can only be considered a spy when, acting clandestinely or on false pretences, he obtains or endeavours to obtain information in the zone of operations of a belligerent, with the intention of communicating it to the hostile party."

The European states that had undergone belligerent occupation during the Second World War, while accepting the basic concept of the Hague Regulations, wished to define the concept somewhat more narrowly in order to protect their own nationals in a situation of belligerent occupation. The first paragraph of article 46 simply provides that a person engaged in espionage shall not have the right to POW status "and may be treated as a spy." There is nothing in this paragraph or in the entire article that suggests that espionage as an activity, or spies as a classification, is unlawful. Paragraph 2 of the article makes it clear that a person gathering information in territory controlled

90. See the statement by U.S. Brigadier General Donald Blackburn (Ret.), concerning his experience while serving as commander of an irregular force in the Philippines during World War II. 70 Ам. Soc. In't' L. Proc. 155 (1976).

91. Geneva Convention for the Amelioration of the Condition of the Wounded and Sick in Armed Forces in the Field of August 12, 1949 [1955] 6 U.S.T. 3114, T.I.A.S. No. 3362, 75 U.N.T.S. 31; Geneva Convention for the Amelioration of the Condition of Wounded, Sick and Shipwrecked Members of the Armed Forces at Sea of August 12, 1949 [1955] 6 U.S.T. 3217, T.I.A.S. No. 3363, 75 U.N.T.S. 85

92. Regulations Annexed to Hague Convention of 1907 , supra note 1. 
by an adverse party is not engaged in espionage if he is wearing the uniform of his armed forces.

Paragraph 3 recognizes that fact situations arise in occupied territory where a member of the armed forces of a party to the conflict is a resident and may well receive information of military significance incidental to his living in the occupied territory. For example, a resident of a small town where an armored column passes can hardly avoid knowledge of this fact. Paragraph 3 provides that such a member of the armed forces who receives information within occupied territory may not be treated as "engaging in espionage unless he does so through an act of false pretences or deliberately in a clandestine manner." In addition, such a resident-member of the armed forces shall not lose his right to POW status if captured unless he is captured while actually engaged in espionage. An illustration is provided in the 1976 Report of Committee III:

For example, the resident who observed military movements while walking along the street or who took photographs from his residence would not be engaged in espionage; whereas the resident who used a forged pass to enter a military base or who, if lawfully on the base, illegally brought a camera with him, would be engaging in espionage. ${ }^{93}$

Paragraph 4 repeats the basic rule in article 31 of the Hague Regulations that a member of the armed forces who is engaged in espionage and then rejoins his unit and is thereafter captured cannot be punished for his prior activities as a spy. A feature of paragraph 4 is that it specifically applies the rule of article 31 of the Hague Regulations to those members of the enemy armed forces who are not resident in occupied territory but carry out espionage there.

Article 46 preserves the basic rules of the Hague Regulations but adds new specifications. The outcome is that members of the armed forces who are engaged in espionage still retain their status as lawful but unprivileged combatants who may have drastic penal sanctions, including the death penalty, imposed upon them if captured under the limited circumstances enunciated. Nothing in article 46 questions or deals with the traditional pattern of drastic sanctions for spies. These sanctions were developed in a situation where the death penalty was considered to be the only effective way in which an enemy power could protect itself from the grave threat posed by espionage. If the purpose of the penalty was to prevent espionage, or even to deter it in some significant degree, it was an ineffective sanction except in preventing further espionage by those convicted of spying. The death penalty is no longer necessary for the latter purpose, since those taken in the act of espionage may now be imprisoned without any practical possibility of escape. Since the death pen-

93. 15 CDDH Official Records, supra note 18, at 373, 388 (CDDH/236/Rev.1). 
alty is now being questioned in all of its aspects as punishment for even the most heinous crimes in domestic law, it is surprising that it is not questioned in international law when applied to those who act for patriotic purposes. It is inconsistent with the fundamental humanitarian objective of Protocol I to impose no limitations upon the customary use of the death penalty as a sanction applied to spies. ${ }^{94}$

\section{B. Unlawful Combatants-Mercenaries}

Article 47 of Protocol I (previously article 42, quater) entitled "Mercenaries" reflects the deep concern of several of the African states relating to the threat posed by mercenaries. Paragraph 1 provides simply that "[a] mercenary shall not have the right to be a combatant or a prisoner of war." This provision, on its face, is consistent with the notion that a mercenary may be merely an unprivileged combatant rather than an unlawful one.

The second paragraph defines a mercenary in restrictive terms by setting forth three affirmative criteria and adding three negative ones. The first affirmative criterion is that a mercenary must be "specially recruited" in order to fight in an armed conflict; the second is that he "does, in fact, take a direct part in the hostilities." This narrows the concept of mercenary by laying aside the uncertainties involved in the possible intention to participate in hostilities at some time in the future and by making the criterion direct participation. The third affirmative requirement is that the person "is motivated to take part in the hostilities essentially by the desire for private gain" and is actually promised, on behalf of a party to the conflict, compensation "substantially in excess of that promised or paid to other combatants of similar ranks and functions." This provision should be interpreted in the light of the customary law background, which characterizes marauders on land and pirates at sea as unlawful combatants who act for private gain rather than for a public purpose.

The first of the negative criteria is that a mercenary "is neither a national of a Party to the conflict nor a resident of territory controlled by a Party to the conflict," and the second is that he is not a member of the armed forces of a party to the conflict. The third negative requirement excludes, inter alia, military attachés and observers since it provides that a mercenary "has not been sent by a State which is not a Party to the conflict on official duty as a member of its armed forces." The breadth of this exclusion rules out armed forces members who are sent as instructors to serve with the armed forces of a party to the conflict.

Article 47 does nothing to diminish the contrast between a spy, who acts for public purposes, and a mercenary, who is motivated "essentially" by the

94. See A. John Armstrong. The Legal Regime of Mercenaries and Freedom Fighters (1977) (unpublished LL.M. thesis in the George Washington University Law Library). 
desire for private material gain and is promised such gain. It is significant that under article $47(2)$ (b) a person must actually participate in hostilities to be classified as a mercenary and cannot claim immunity from prosecution for any acts of hostilities or war. Article $\mathbf{4 7}$ defines mercenaries so narrowly that a person with reasonably competent legal advice should be able to provide needed military services to a party to the conflict and remain beyond the scope of the definition.

Article 75 of Protocol I (previously article 65) deals with fundamental humanitarian guarantees for persons who are not entitled to more favorable treatment under the provisions of Protocol I or the 1949 Geneva Conventions. At the time article 75 was adopted by the Plenary by consensus ${ }^{95}$ there was no dissent from the statement of the Greek delegate that it applied to mercenaries. ${ }^{96}$

\section{IV}

\section{Protocol I Policy and Enforcement}

The most significant policy aspect of Protocol $I$ is the bringing of wars of national liberation-the CAR conflicts of article 1(4)-specifically within the legal system of the Geneva Conventions of 1949 and the international conflicts Protocol. ${ }^{97}$ The alleged revolutionary character of article 1(4), including the view that it is an attack upon international law, ${ }^{98}$ is a doubtful premise. It is difficult to ascribe a rational meaning to the "organized resistance movements," the members of which have privileged combatant status under the presently effective 1949 POW Convention, ${ }^{99}$ unless such movements have the legal right to fight "against colonial domination and alien occupation and against racist regimes." Marshal Tito's partisans of World War II fame were the principal model that influenced the inclusion of such movements in the 1949 treaty law. ${ }^{100}$ It is well established that they conducted their hostilities against the Nazi occupation, which had all three of the characteristics of the

\footnotetext{
95. 6 CDDH Official Records, supra note 18, at 243, 250 (CDDH/SR.43).

96. Id. at 249 .

97. The value-conserving policy of Protocol I was not the first step taken to promote humanity in dealing with irregulars. During the Southeast Asia conflict, the U.S. Government accorded POW status upon capture to irregulars under the criteria of U.S. Army Military Assistance Command, Vietnam (MACV) Directive 381-46 (December 27, 1967), which accorded POW status to irregulars who did not meet the requirements of article $4 \mathrm{~A}(2)$ of the Geneva POW Convention. See 62 Ам. J. INT'L L. 765, 766 (1968). The MACV Directive is analyzed in Mallison \& Mallison, supra note 2 , at $72-74$.

98. See Graham, The 1974 Diplomatic Conference on the Law of War: A Victory for Political Causes and a Return to the "Just War" Concept of the Eleventh Century, 32 WASH. \& LeE L. Rev. 25 (1975). Captain Graham characterizes the attitude of the third world proponents of draft article 1(2) (as it was in 1974) as, "The law be damned-we won." Id. at 61 (emphasis in original). Bond, supra note 50 , at $65-78$, provides a thoughtful response.
}

99. POW Convention, supra note 1 , at art. $4 \mathrm{~A}(2)$ at 3320.

100. Mallison \& Mallison, supra note 2 , at 52,54 . 
CAR regimes specified in article 1(4). Because of the presently effective law concerning organized resistance movements, it may be that article 1(4) is not a law-making provision, as is widely believed, but merely a declaratory reiteration of a principle written into law in 1949. Article 1(4) must nevertheless be appraised as a meaningful method of resolving possible ambiguities and promoting the application of international humanitarian law in conflicts that are notorious for their inhumanity.

Through the adoption of the articles concerning privileged combatant status that have been considered in the present study, the Geneva Diplomatic Conference has manifested a world community policy that develops the international law of armed conflict in a number of significant respects. For the first time, the international humanitarian law expressly treats regular and irregular armed forces in precisely the same way. ${ }^{101}$ In particular, under the second sentence of article 44(3), combatants, without distinction, may retain combatant status provided that they meet the minimum requirement specified by the sentence-open carrying of arms. ${ }^{102}$ This means that in particular circumstances irregulars may dispense with the fixed distinctive sign, which has been one of their traditional requirements, while regulars in the same limited circumstances may dispense with their equally traditional requirement of a military uniform. ${ }^{103}$ This amounts to a significant lowering of the criteria for privileged combatant status, but only in the limited circumstances specified by article 44(3). The new criteria are quite similar to those applicable to the levée en masse in the 1949 POW Convention, which are only open bearing of arms and adherence to the laws and customs of war. ${ }^{104}$

It is clear that dissemination of knowledge and understanding concerning the law of armed conflict is an indispensable first step to more adequate enforcement. Article 83 sets forth an undertaking to disseminate the Conventions and Protocol I and to include study of them in military instruction programs as well as to encourage civilian study. This supplements the educational requirements of article 43(1), which are applicable to both regulars and irregulars. The Henri Dunant Institute, the research arm of the ICRC, has performed a role of international leadership in education in this field. For example, in late November and early December 1977, this Institute cooperated with the International Relations Institute of Cameroon in conducting the First

101. In articles $4 \mathrm{~A}(1)$ and $4 \mathrm{~A}(3)$ of the 1949 POW Convention concerning regular armed forces, the four criteria applicable to irregulars are not expressly applied to regulars, but these are deemed applicable through necessary implication and the customary law. See Mallison \& Mallison, supra note 2, at 48; POW Convention, supra note 1, at art. 4A(2).

102. In 1973 Ambassador Aldrich had extraordinary prescience in predicting the limited requirements of article $44(3)$ in his address, Human Rights in Armed Conflicts: Development of the Law, 68 Dep't State Bull. 876,878 (1973).

103. Criticism of the clothing of a combatant as determining the difference between life and death has been made in Baxter, supra note 4 , at 343 .

104. POW Convention, supra note 1 , at art. $4 \mathrm{~A}(6), 6$ U.S.T. 3316 , at 3322. 
African Seminar on International Humanitarian Law at Yaoundé. ${ }^{105}$ The seminar consisted of lectures along with discussion periods conducted by leading legal authorities. The participants were military officers, diplomats, lawyers, university professors, and medical doctors, as well as officers of the Henri Dunant Institute, the ICRC, and the Cameroon National Red Cross. Seventy participants from twenty-three African countries attended the seminar. There is an urgent need for more educational programs of this type for both armed forces and civilians to lay the basis for a better informed public opinion.

While the policy of Protocol I represents a broad international consensus, its administration is substantially national in many important respects. Thus, the criteria of articles $1,43,44,46$, and 47 are to be interpreted and applied in practice by the enemy power that has captured the individual who claims privileged combatant status. The temptation to indulge in idiosyncratic national interpretations exists during peacetime. In time of international conflict, immediate military advantage, or national misperceptions concerning it, can lead to interpretations that would substantially frustrate the policy of Protocol I. An enlightened and aroused world public opinion, however, can promote the achievement of human rights by making an impact on national decisionmakers even in wartime. In the same way, public opinion can compel state-parties to the Protocol "to respect and to ensure respect for this Protocol in all circumstances." An effective sanctioning process, like the multilateral law-making process in Geneva from 1974 to 1977 , is dependent upon the identification and implementation of common values, not upon common ideologies. ${ }^{106}$

In summary, the key provisions of Protocol I bring irregular forces within the law of armed conflict whether they are termed national liberation movements, authorities representing peoples, organized resistance movements, or any other name. The result is the establishment of a reciprocal system of legal rights conditioned upon the observance of obligations upon all armed forces. This offers the prospect of promoting the central humanitarian objective of the international law of armed conflict by minimizing the destruction of human and material values.

105. See Report of the First African Seminar on International Humanitarian Law (1977) (Henri Dunant Institute and International Relations Institute of Cameroon).

106. The centrality of values in an effective sanctioning process is made explicit in $M$. McDougal \& F. Feliciano, Law and Minimum World Public Order, ch. 4 (1961).

Protocol I establishes sanctions, doctrines, and institutions that are heavily dependent upon the factors mentioned in this study. Protocol I, pt. V, sec. II, Repression of Breaches of the Conventions and of This Protocol (arts. 85-91). Its article 85, inter alia, makes direct attacks on civilians a grave breach (see also art. 11). Article 88 provides for mutual assistance concerning criminal proceedings connected with grave breaches. Article 90 establishes an international fact-finding commission. 


\section{APpendix A}

\section{Preamble}

\section{The High Contracting Parties,}

Proclaiming their earnest wish to see peace prevail among peoples,

Recalling that every State has the duty, in conformity with the Charter of the United Nations, to refrain in its international relations from the threat or use of force against the sovereignty, territorial integrity or political independence of any State, or in any other manner inconsistent with the purposes of the United Nations,

Believing it necessary nevertheless to reaffirm and develop the provisions protecting the victims of armed conflicts and to supplement measures intended to reinforce their application,

Expressing their conviction that nothing in this Protocol or in the Geneva Conventions of 12 August 1949 can be construed as legitimizing or authorizing any act of aggression or any other use of force inconsistent with the Charter of the United Nations,

Reaffirming further that the provisions of the Geneva Conventions of 12 August 1949 and of this Protocol must be fully applied in all circumstances to all persons who are protected by those instruments, without any adverse distinction based on the nature or origin of the armed conflict or on the causes espoused by or attributed to the Parties to the conflict,

Have agreed on the following:

\section{Article I-General principles and scope of application}

1. The High Contracting Parties undertake to respect and to ensure respect for this Protocol in all circumstances.

2. In cases not covered by this Protocol or by other international agreements, civilians and combatants remain under the protection and authority of the principles of international law derived from established custom, from the principles of humanity and from the dictates of public conscience.

3. This Protocol, which supplements the Geneva Conventions of $12 \mathrm{Au}$ gust 1949 for the protection of war victims, shall apply in the situations referred to in Article 2 common to those Conventions.

4. The situations referred to in the preceding paragraph include armed conflicts in which peoples are fighting against colonial domination and alien occupation and against racist régimes in the exercise of their right of self-determination, as enshrined in the Charter of the United 
Nations and the Declaration on Principles of International Law concerning Friendly Relations and Co-operation among States in accordance with the Charter of the United Nations.

\section{Appendix B}

Article 43-Armed forces

1. The armed forces of a Party to a conflict consist of all organized armed forces, groups and units which are under a command responsible to that Party for the conduct of its subordinates, even if that Party is represented by a government or an authority not recognized by an adverse Party. Such armed forces shall be subject to an internal disciplinary system which, inter alia, shall enforce compliance with the rules of international law applicable in armed conflict.

2. Members of the armed forces of a Party to a conflict (other than medical personnel and chaplains covered by Article 33 of the Third Convention) are combatants, that is to say, they have the right to participate directly in hostilities.

3. Whenever a Party to a conflict incorporates a paramilitary or armed law enforcement agency into its armed forces it shall so notify the other Parties to the conflict.

\section{APpendix C}

\section{Article 44-Combatants and prisoners of war}

1. Any combatant, as defined in Article 43, who falls into the power of an adverse Party shall be a prisoner of war.

2. While all combatants are obliged to comply with the rules of international law applicable in armed conflict, violations of these rules shall not deprive a combatant of his right to be a combatant or, if he falls into the power of an adverse Party, of his right to be a prisoner of war, except as provided in paragraphs 3 and 4.

3. In order to promote the protection of the civilian population from the effects of hostilities, combatants are obliged to distinguish themselves from the civilian population while they are engaged in an attack or in a military operation preparatory to an attack. Recognizing, however, that there are situations in armed conflicts where, owing to the nature of the hostilities an armed combatant cannot so distinguish himself, he shall retain his status as a combatant, provided that, in such situations, he carries his arms openly:

(a) during each military engagement, and

(b) during such time as he is visible to the adversary while he is en- 
gaged in a military deployment preceding the launching of an attack in which he is to participate.

Acts which comply with the requirements of this paragraph shall not be considered as perfidious within the meaning of Article 37, paragraph $1(c)$.

4. A combatant who falls into the power of an adverse Party while failing to meet the requirements set forth in the second sentence of paragraph 3 shall forfeit his right to be a prisoner of war, but he shall, nevertheless, be given protections equivalent in all respects to those accorded to prisoners of war by the Third Convention and by this Protocol. This protection includes protections equivalent to those accorded to prisoners of war by the Third Convention in the case where such a person is tried and punished for any offences he has committed.

5. Any combatant who falls into the power of an adverse Party while not engaged in an attack or in a military operation preparatory to an attack shall not forfeit his rights to be a combatant and a prisoner of war by virtue of his prior activities.

6. This Article is without prejudice to the right of any person to be a prisoner of war pursuant to Article 4 of the Third Convention.

7. This Article is not intended to change the generally accepted practice of States with respect to the wearing of the uniform by combatants assigned to the regular, uniformed armed units of a Party to the conflict.

8. In addition to the categories of persons mentioned in Article 13 of the First and Second Conventions, all members of the armed forces of a Party to the conflict, as defined in Article 43 of this Protocol, shall be entitled to protection under those Conventions if they are wounded or sick or, in the case of the Second Convention, shipwrecked at sea or in other waters.

\section{APPEndix D}

Article 96-Treaty relations upon entry into force of this Protocol

1. When the Parties to the Conventions are also Parties to this Protocol, the Conventions shall apply as supplemented by this Protocol.

2. When one of the Parties to the conflict is not bound by this Protocol, the Parties to the Protocol shall remain bound by it in their mutual relations. They shall furthermore be bound by this Protocol in relation to each of the Parties which are not bound by it, if the latter accepts and applies the provisions thereof.

3. The authority representing a people engaged against a High Contracting Party in an armed conflict of the type referred to in Article 1, 
paragraph 4, may undertake to apply the Conventions and this Protocol in relation to that conflict by means of a unilateral declaration addressed to the depositary. Such declaration shall, upon its receipt by the depositary, have in relation to that conflict the following effects:

(a) the Conventions and this Protocol are brought into force for the said authority as a Party to the conflict with immediate effect;

(b) the said authority assumes the same rights and obligations as those which have been assumed by a High Contracting Party to the Conventions and this Protocol; and

(c) the Conventions and this Protocol are equally binding upon all Parties to the conflict. 